\title{
Política indutora de educação integral: análise dos programas implementados em Belterra/PA
}

\author{
Inducing policy of integral education: analysis of the program \\ implemented in Belterra/PA
}

\section{Inducir la política de educación integral: analisis de las programas implementados en Belterra/PA}

\author{
Lília Travassos de Sousa' \\ Universidade Federal do Oeste do Pará, Grupo de estudos e pesquisas HISTEDBR, \\ Pesquisadora. \\ https://orcid.org/0000-0001-9054-5087 \\ Maria Lília Imbiriba Sousa Colares² \\ Universidade Federal do Oeste do Pará, Programa de Pós-Graduação em Educação, \\ Professora. \\ https://orcid.org/0000-0002-5915-6742
}

Resumo: Este estudo aborda as políticas educacionais indutoras de Educação Integral a partir da análise dos programas implementados pela Secretaria Municipal de Educação e Desporto (SEMED) de Belterra/PA. A pesquisa é norteada pela seguinte questão: Quais programas de Educação Integral foram implementados pela SEMED de Belterra/PA, tendo como base a constituição do currículo, da infraestrutura e do financiamento desses programas? A metodologia da pesquisa consistiu na revisão bibliográfica, levantamento e análise documental. Constatou-se que a SEMED não desenvolveu programas locais de Educação Integral, porém, implementou políticas educacionais advindas do governo federal tais como o Programa Mais Educação (PME) em 2012 e a partir do ano de 2016 do Programa Novo Mais Educação (PNME). Identificamos que o atraso no repasse das verbas para a execução do PME e PNME ocasionou paralização, mesmo que temporária, das atividades cujo objetivo principal é melhorar a aprendizagem dos estudantes com baixo desempenho escolar e com vulnerabilidade social, mediante a ampliação do currículo escolar e do tempo de permanência na escola. 0 estudo conclui que apesar da Educação Integral não estar intrinsecamente ligada a extensão do tempo escolar, evidenciamos que para melhor efetivá-la devemos pensar em uma ampliação do currículo, da infraestrutura lespaços e organização do tempo) e do financiamento.

Palavras-chave: Educação Integral. Currículo. Infraestrutura. Financiamento.

Mestra em Educação pela Universidade Federal do Oeste do Pará; pós-graduanda em Educação Especial e Inclusiva pela Faculdade Venda Nova do Imigrante.

2 Pós-doutora e Doutora em Educação pela Universidade Estadual de Campinas. 
Abstract: This study addresses the educational policies that induce Integral Education from the analysis of the programs implemented by the Municipal Education and Sport Secretariat (SEMED) of Belterra/PA. The research is guided by the following question: Which Integral Education programs were implemented by SEMED in Belterra/PA, based on the constitution of the curriculum, infrastructure and financing for these programs? The research methodology consisted of literature review, survey and document analysis. It was found that SEMED did not develop local Integral Education programs, however, it implemented educational policies from the federal government such as the More Education Program (PME) in 2012 and from the year 2016 of the new more education Program (PNME). We identified that the delay in the transfer of funds for the execution of the PME and PNME caused paralysis, even if temporary, of the activities whose main objective is to improve the learning of students with low school performance and social vulnerability, by expanding the school curriculum and the time spent in school. The study concludes that despite Integral Education is not intrinsically linked to the extension of school time, we show that, in order to improve it, we must think about expanding the curriculum, infrastructure (spaces and organization of time) and financing.

Keywords: Integral Education. Curriculum. Infrastructure. Financing.

Resumen: Este estudio aborda las politicas educativas que inducen la Educación Integral del análisis de los programas implementados por el Departamento Municipal de Educación y deport (SEMED) de Belterra/ PA. La investigación se guía por la siguiente pregunta: ¿Qué programas de Educación Integral fueron implementados por la SEMED em Belterra/PA, con base en la constitución del currículo, infraestructura y financiamento de estos programas? La metodología de investigación consistió en revisión bibliográfica, encuesta y análisis documental. Se encontró que SEMED no desarrolló programas locales de Educación Integral, sin embargo, implementó políticas educativas del gobierno federal como el Programa Más Educativo (PME) en 2012 y a partir de 2016 el Programa Novo Mais Educación (PNME). Identificamos que el retraso en la transferencia de fondos para la ejecución de la PME y la PNME causó la paralización, aunque sea temporal, de las actividades cuyo principal objetivo es mejorar el aprendizaje de los estudiantes con bajo rendimiento escolar y vulnerabilidad social, a través de la expansión del currículo escolar y la duración de la estancia en la escuela. El estúdio concluye qué aunque la Educación Integral no está intrínsecamente ligada a la ampliación del tiempo escolar, demostramos que para afectarla mejor debemos pensar en una expansión del currículo, la infraestructura lespacios y organización del tiempo) y la financiación.

Palabras clave: Educación Integral. Reanudar. Infraestructura. Financiación.

Recebido em 16 de novembro de 2020 Aceito em 15 de fevereiro de 2021 


\section{INTRODUÇÃO}

A Educação Integral no processo educacional brasileiro, de acordo com Gadotti (2009), foi introduzida a partir do "Manifesto dos Pioneiros da Educação Nova" de 1932, no qual defendia uma escola pública laica e obrigatória, o que a condicionava a ser gratuita, sendo efetivada por meio da concepção de Educação Integral, pois havia a necessidade de uma educação para todos, que desenvolvesse plenamente o ser humano em cada etapa de sua vida, tendo o Estado como responsável pela garantia desse direito, como podemos evidenciar no próprio Manifesto (1932) ao afirmar que o "direito biológico de cada indivíduo à sua Educação Integral, cabe evidentemente ao Estado a organização dos meios de o tornar efetivo, por um plano geral de educação, de estrutura orgânica, que torne a escola acessível, em todos os seus graus." (AZEVED0 et al., 2006, p. 193).

Um dos marcos legais ${ }^{3}$ na institucionalização da Educação Integral foi a promulgação da Constituição Federal (CF) de 1988, art. 205, sendo posteriormente, ratificada na Lei de Diretrizes e Bases da Educação Nacional - LDB n 9.394/96, no art. 2, responsabilizando o Estado, a família e a sociedade na promoção do pleno desenvolvimento da pessoa, preparando-a para o exercício da cidadania e sua qualificação para o trabalho. Considerando os discursos oficiais acerca da Educação Integral, Gomes (2017, p. 46) afirma que ela deve ser analisada como capaz de melhorar o processo de aprendizagem "ao possibilitar o desenvolvimento de atitudes que consideram a heterogeneidade, a autonomia, a criatividade, bem como os saberes constituídos pelas experiências vivenciadas pelos alunos em seu dia a dia."

Este estudo integrou o projeto "As experiências pedagógicas das políticas de educação integral na Amazônia: rede de pesquisas e formação acadêmica", com a Universidade Estadual de Campinas (UNICAMP), Universidade Federal de Rondônia (UNIR) e Universidade Federal do Oeste do Pará (UFOPA) cujo objetivo foi analisar e caracterizar as produções sobre Educação Integral realizadas nos Estados do Pará, Amazonas e Rondônia. É também um recorte dos estudos em andamento no projeto de pesquisa intitulado " $A$ implementação da educação integral na Região Metropolitana de Santarém", estudos sobre educação integral nos municípios de Santarém, Belterra e Mojuí dos Campos, vinculados ao Grupo de Estudos e Pesquisas "História, Sociedade e Educação no Brasil" (HISTEDBR-UFOPA) e financiado pelo Conselho Nacional de Desenvolvimento Cientifico e Tecnologia (CNPq).

3 São eles: CF (BRASIL, 1988); LDB (9.394/96) (BRASIL, 1996); Plano Nacional de Educação - PNE (BRASIL, 2014); PME (17/2007) (BRASIL, 2007); PNME (1.144/2016) (BRASIL, 2016).

4 Projeto Coordenado pela Profa. Dra. Maria Lilia Imbiriba Sousa Colares, Bolsista produtividade em pesquisa na chamada CNPq n. $9 / 2018$. 
Tem como enfoque as políticas indutoras de Educação Integral, norteado pela seguinte questão: Quais programas de Educação Integral foram implementados pela Secretaria Municipal de Ensino e Desporto (SEMED) de Belterra/PA, tendo como base a constituição do currículo, da infraestrutura e do financiamento desses programas? Para responder esse questionamento trabalhamos com o objetivo de analisar os programas de Educação Integral implementados pela Secretaria Municipal de Educação e Desporto/SEMED de Belterra/PA, considerando a constituição do currículo, da infraestrutura e do financiamento.

Foram realizados os estudos bibliográficos por meio do levantamento da literatura especializada e normativa para o embasamento de questões conceituais, apoiando-se nas concepções sobre Educação Integral de autores como Cavalieri (2007), Coelho (2009), Esquinsani (2010), Arroyo (2012), Ferreira (2016), Gadotti (2009), Maurício (2016), Gomes (2017), Monteiro (2018), Maciel (2018), Gomes e Colares (2019) e Silva e Colares (2020). 0 levantamento e análise dos dados partiu da legislação, que aborda a temática da Educação Integral e em Tempo Integral, como: Constituição Federal de 1988, LDB - 9.394/96, PNE 13.005/2014, PME - 17/2007, 1.144/2016 (BRASIL, 2016a). Integram também, os documentos de domínio público ${ }^{5}$ obtidos por meio de sites do governo, que detém informações relevantes para a pesquisa, bem como aqueles que são acessados somente pelo coordenador municipal do Programa (Planos de atendimento Consolidado PME e PNME) e os fornecidos pela Secretaria Municipal de Educação e Desporto (SEMED) de Belterra/PA (Plano de ação do PME, Cronograma de atividades do PME e PNME, Ata de reunião do programa PME).

Para apresentação dos resultados do estudo, este artigo está composto por três seções, na qual a primeira corresponde à introdução. A segunda "As propostas dos programas de educação integral em Belterra/PA quanto ao currículo, infraestrutura e financiamento" apresenta a caracterização do lócus da pesquisa a partir da implementação dos programas de Educação Integral nesse município, abordando em seguida, as propostas, por meio de documentos orientadores da Educação Integral (PME e PNME), que evidenciam questões relacionadas ao currículo, à infraestrutura e ao financiamento, buscando identificar as aproximações e/ou divergências dos programas. As considerações finais sobre essa temática encerram a terceira e última seção deste texto.

5 Censo Escolar (Matrículas, Rendimento Escolar, Distorção ldade-série), Índice de Desenvolvimento da Educação Básica - IDEB, Extrato de Liberações de recursos, documentos referentes ao município de Belterra entre 2012 a 2018 pesquisados nos sites Qedu.org.br, Inep.gov.br, lbge.gov.br, Fnde.gov.br (PDDE/Educaçãolntegral) (Todos disponibilizados nas referências deste artigo). 


\section{PROGRAMAS INDUTORES DE EDUCAÇÃO INTEGRAL: CURRÍCULO, INFRAESTRUTURA E FINANCIAMENTO}

\subsection{CARACTERIZAÇÃO DO LÓCUS DE PESQUISA A PARTIR DA IMPLEMENTAÇÃO DOS PROGRAMAS DE EDUCAÇÃO INTEGRAL}

Belterra é um município brasileiro localizado na região Oeste do estado do Pará, sendo uma das mesorregiões que compõem o Baixo-Amazonas, pertencendo a Região metropolitana de Santarém, ${ }^{6}$ na qual faz divisa com essa cidade além de Mojuí dos Campos, Placas, Rurópolis e Aveiro. "Um aspecto peculiar [...] é a localização do município e sua história no interior da Amazônia, com origem a partir de uma política governamental para o desenvolvimento da região amazônica, por meio da Empresa Norte Americana de Henry Ford." (SANTOS; COLARES, 2019, p. 335). Segundo os dados do último censo do Instituto Brasileiro de Geografia e Estatística - IBGE (2010), a população é de 16.318 mil habitantes com estimativa de 17. 624 mil habitantes para 2018, em uma área de 4.398,419 kma, contendo 3,71 (hab/kma) de Densidade Demográfica e 0,588 de Índice de Desenvolvimento Humano Municipal (IDHM).

A Educação Integral em Belterra/PA, iniciou com a implementação do Programa Mais Educação (PME), instituído pelo governo federal cujo objetivo era promover por meio da extensão do tempo escolar, uma educação que contemplasse uma formação completa para os alunos do ensino fundamental.

0 PME em Belterra começou a ser implementado em 2012, a partir da adesão das escolas por meio da SEMED. A adesão ao programa foi realizada, considerando os critérios estabelecidos pelo Fundo Nacional de Desenvolvimento da Educação (FNDE): Escolas com Baixo Índice de Desenvolvimento da Educação Básica (IDEB) com os alunos em situação de vulnerabilidade social, sendo composto por 50 \% de oriundos do Bolsa Família.

Após as instituições escolares serem contempladas com o PME, as escolas selecionavam as atividades que seriam trabalhadas nas horas complementares, podendo ser atividades que integravam os diversos macrocampos de conhecimentos: Acompanhamento pedagógico, Meio Ambiente, Esporte e lazer, Direitos Humanos, Promoção à saúde, Cultura e artes, Inclusão digital, Educomunicação, Iniciativa à investigação das Ciências da natureza, Educação e cidadania. As escolas da zona urbana poderiam optar por trabalhar com 5 ou 6 atividades de 4 macrocampos diferentes e as escolas da zona rural tinham que escolher

\footnotetext{
6 De acordo com o IBGE (2017), Belterra pela lei estadual n 62, de 31-12-1947, deixa de pertencer ao distrito de Alter do Chão, e é elevado à categoria de distrito, ambos subordinados ao município de Santarém. E somente em 29 de dezembro de 1995, por meio da lei estadual $n^{\circ} 5928 / 95$, Belterra é emancipada.
} 
4 atividades, mas ambas deveriam incluir obrigatoriamente dentro de suas escolhas o acompanhamento pedagógico, que era o macrocampo composto por: Matemática, Letramento, Linguas Estrangeiras, Ciências, História e Geografia, Filosofia e Sociologia.

Considerando que o município de Belterra divide-se em 1 zona urbana e 2 zonas rurais (Tapajós e BR 163), identificamos por meio do quadro 1, o número de escolas e alunos que participaram do programa Mais Educação de 2012 a 2015, tempo de vigência do referido programa antes da reformulação para o Novo Mais Educação.

Tabela 1 - Quantidade de escolas e alunos beneficiados pelo PME por zona no período de 2012 a 2015

\begin{tabular}{|c|c|c|c|}
\hline \multirow[t]{2}{*}{$\operatorname{Ar}$} & \multirow[t]{2}{*}{ Zona } & \multicolumn{2}{|c|}{ Quantidade } \\
\hline & & Escolas & Alunos \\
\hline & Urbana & 2 & 185 \\
\hline \multirow[t]{3}{*}{2012} & Rural (BR 163) & 3 & 276 \\
\hline & Rural (Tapajós) & 6 & 526 \\
\hline & Urbana & 6 & 523 \\
\hline \multirow[t]{3}{*}{2013} & Rural (BR 163) & 3 & 276 \\
\hline & Rural (Tapajós) & 10 & 694 \\
\hline & Urbana & 6 & 523 \\
\hline \multirow[t]{2}{*}{2014} & Rural (BR 163) & 2 & 195 \\
\hline & Rural (Tapajós) & 9 & 655 \\
\hline 2015 & Rural (BR 163) & 1 & 95 \\
\hline
\end{tabular}

Fonte: elaborada pelos autores, com base nas informações disponibilizadas pela SEMED/Belterra-PA.

De acordo com a Tabela 1, podemos constatar que em 2012 onze escolas foram contempladas com o PME, pois estavam com o conselho escolar regular, uma das exigências para a adesão ao programa. Em 2013, 17 conselhos escolares estavam aptos a se cadastrar e receber o recurso para a implementação do PME, no qual 19 escolas foram beneficiadas, porque dois conselhos escolares agregaram mais duas escolas, cada. Em 2014, 17 escolas receberam os recursos advindos do programa, sendo que em 2015 apenas uma escola ${ }^{7}$ continuou recebendo o recurso e a partir de 2016 houve a adesão no PNME, com 7 escolas beneficiadas.

No ano de 2016, o programa do governo federal indutor de Educação Integral PME, depois de nove anos desenvolvendo atividades em escolas públicas brasileiras, iniciou um processo de reformulação mudando o foco dessa política educacional, que antes era pautada

7 Essa escola deu continuidade ao PME, pois recebeu a $2^{a}$ parcela do recurso referente ao exercício de 2014, conseguindo efetivá-lo até o primeiro semestre de 2015, paralisando em seguida as atividades do programa por falta de recurso. 
na oferta de atividades diversificadas com o intuito de promover o desenvolvimento pleno do aluno, passando desde então a objetivar um melhoramento da aprendizagem em língua portuguesa e matemática no ensino fundamental, por meio da ampliação da jornada escolar de crianças e adolescentes.

As atividades do Programa Novo Mais Educação estão estritamente relacionadas às disciplinas de Língua Portuguesa e Matemática, sendo que as escolas podem escolher um dos dois tipos de carga horária que o programa oferece, 5 h ou $15 \mathrm{~h}$ semanais, em que optando por $5 \mathrm{~h}$ /Semanais essas horas são distribuídas igualmente para serem trabalhadas entre as disciplinas de Língua Portuguesa e matemática, mas se a escola quiser aderir a jornada semanal de 15 horas, terá que dedicar 4 horas semanais para Língua Portuguesa e mais $4 \mathrm{~h}$ semanais para matemática, e a carga horária restante poderá ser utilizada para trabalhar as atividades que integram os campos das artes, cultura, esporte e lazer, como forma de melhorar o desempenho educacional das escolas participantes.

Em Belterra, as escolas da rede municipal participaram no final de 2016 da adesão do PNME, no qual foram contempladas apenas 7 escolas, sendo 1 com carga horária de $5 \mathrm{~h} /$ semanais e as demais com 15h/semanais, no qual em 2017 essas escolas continuaram compondo o programa. Em 2018, das escolares anteriores, uma delas não permaneceu no programa, mas houve a inclusão de 2 instituições escolares, sendo uma (1) delas com carga horária de 5 horas.

Para a adesão do PNME, as escolas pretendentes deveriam cumprir os seguintes critérios: Ter recebido recursos do PDDE Educação Integral entre 2014 e 2016; apresentar Índice de Nível Socioeconômico baixo ou muito baixo segundo a classificação do Instituto Nacional de Estudos e Pesquisas Educacionais Anísio Teixeira (INEP); terem obtido baixo desempenho no Índice de Desenvolvimento da Educação Básica - IDEB. E os alunos participantes do PNME, são os que estão desde $\circ 3^{\circ}$ ao $9^{\circ}$ ano do ensino fundamental com baixo desempenho escolar e/ou alta vulnerabilidade social concentrados, principalmente, nos $4^{\circ}, 6^{\circ}$ e $8^{\circ}$ anos do ensino fundamental (BRASIL, 2016).

Como podemos verificar, a implementação é uma das etapas que consideramos necessitar de um acompanhamento em sua execução, tendo em vista a sua importância para o bom desempenho de programas e projetos no âmbito educacional. Diante disso, apresentamos a seguir como se constituiu o currículo, a infraestrutura e o financiamento do PME e PNME na rede municipal de ensino de Belterra/PA. 


\subsection{A EDUCAÇÃO INTEGRAL E O CURRÍCULO NO PME E PNME}

0 currículo do Programa Mais Educação era composto por 10 macrocampos, já citados anteriormente, que segundo o Manual operacional de Educação Integral (2013), propiciava aos participantes do programa entrarem em contato com experiências socioeducativas capazes de favorecer uma educação mais completa. Portanto, as instituições escolares ao aderir o PME, deveriam escolher as atividades com base no seu Projeto Político Pedagógico, considerando a realidade que estão inseridas. $E$ dessa forma, as escolas municipais de Belterra constituiram o currículo do PME conforme os dados dos Planos de Atendimento Consolidados de 2012 a 2015:

a) Escolas da Zona Urbana: acompanhamento pedagógico (Orientação de estudos e leitura, Língua Portuguesa: ênfase em leitura e produção textual, Alfabetização/letramento, Matemática; Esporte e Lazer (Atletismo, basquete, futebol, handebol, voleibol, xadrez, recreação e Lazer/Brinquedoteca; Cultura, Artes e Educação Patrimonial Iniciação musical por meio da flauta doce, Banda, Pintura, dança, Canto coral; Comunicação, uso de mídias e cultura digital e tecnológica (Ambientes de redes sociais, Rádio escolar, Jornal escolar; Educação em direitos humanos; Educação Ambiental, desenvolvimento sustentável e economia solidária e criativa/ educação econômica Horta escolar e/ou comunitária).

b) Escolas da zona Rural: acompanhamento pedagógico (Matemática, Letramento e alfabetização, Línguas Estrangeiras, Ciências, História e Geografia, Filosofia e Sociologia); Esporte e Lazer (Atletismo, basquete, futebol, handebol, voleibol, xadrez, recreação e Lazer/Brinquedoteca); Cultura, Artes e Educação Patrimonial (Musica, Teatro, Pintura e danças); Memória e História das comunidades tradicionais (Brinquedos e artesanato regional); Agroecologia (canteiros sustentáveis).

As escolas da zona urbana, poderiam escolher até 6 atividades, sendo que aquelas que optaram pelas 6 , constituiram seu currículo com 5 atividades de diferentes macrocampos, dentre elas 0 acompanhamento pedagógico, como atividade obrigatória, e a sexta acabava pertencendo a um macrocampo já escolhido, como Esporte e Lazer ou Cultura, Artes e Educação Patrimonial. As escolas da zona rural, deveriam escolher até 4 atividades de macrocampos espećíicos, de acordo com o manual operacional do PME (2013), em que trabalhariam o currículo embasando seus eixos nas categorias Terra, Cultura e 
Trabalho, considerando os seguintes macrocampos específicos: Acompanhamento Pedagógico (obrigatório para as escolas da zona urbana e rural); Agroecologia; Iniciação Científica; Educação em Direitos Humanos; Cultura, Artes e Educação Patrimonial; Esporte e Lazer; e Memória e História das Comunidades Tradicionais.

Em Belterra, cada escola definia um cronograma, onde deveriam conter as atividades trabalhadas na semana, sendo destinada diariamente para esse programa 3 horas, que eram divididas entre duas atividades de macrocampos diferentes. Os monitores, responsáveis pelo acompanhamento pedagógico se concentravam em: Orientação de estudos e leitura, Língua Portuguesa com ênfase em leitura e produção textual, Alfabetização/ letramento e matemática), ficavam no início do ano letivo, uma semana observando os alunos que apresentavam mais dificuldades nessas disciplinas, e em consonância com o professor da sala de aula, escolhiam os alunos que deveriam participar do PME, sendo ofertado no contraturno durante dois dias da semana 1 h e $30 \mathrm{~min}$ cada, para a realização de atividades de natureza lúdica, trabalhadas por meio de jogos pedagógicos que tivessem como objetivo auxiliar no processo de aprendizagem da leitura, escrita e matemática.

Arroyo (2012) enfatiza que esses programas de Educação Integral trazem em sua essência o ato político de assegurar aos educandos mais tempo de formação, como forma de desenvolvê-los plenamente, pois caso esses programas sejam desvirtuados desse sentido político, ficará limitado "a oferecer mais tempo da mesma escola, ou mais um turno - turno extra -, ou mais educação do mesmo tipo de educação. Uma dose a mais para garantir a visão tradicional do direito à escolarização." (ARROYO, 2012, p. 33). Sousa e Colares (2018, p. 104) enfatizam que "a Educação Integral não precisa necessariamente ser em tempo integral para desenvolver integralmente o individuo, mas a escola deve considerar a necessidade de mais tempo e mais espaços."

A principal modificação do PME para o PNME está na constituição do seu currículo, pois enquanto o PME ofertava atividades variadas possibilitando trabalhar com conteúdos diversificados, o PNME centra suas atividades no reforço escolar das disciplinas de Língua Portuguesa e Matemática, emergindo como estratégia para o melhoramento dos índices educacionais.

\footnotetext{
No que tange à organização do ambiente escolar e dos inúmeros processos em torno das avaliações educacionais, é visivel que esta se torna o principal foco nas instituições de ensino [...] compreendidas a partir do caráter ideológico assumido pelos formuladores de políticas educacionais [...] (SOARES; COLARES, 2020, p. 17).
}

Nessa perspectiva, Monteiro (2018, p. 66, grifo do autor) afirma que 
A fundamentação do Novo Mais Educação, apoiada na avaliação sobre o não atingimento das metas do ldeb, está associada a concepções de educação integral que relacionam qualidade da educação a resultados de proficiência dos estudantes, numa perspectiva de negação das relações da educação com os contextos social, econômico e pedagógico em que se inserem as escolas públicas no Brasil.

As áreas em destaque do PMNE são a Língua Portuguesa e a Matemática, preterindo dessa forma as outras disciplinas formativas que compõem o currículo regular das escolas, e para aparentar que não houve um desmonte significativo desse programa no que tange a ampliação de conhecimentos, permaneceram atividades relacionadas ao esporte, lazer, artes e cultura como contribuição para uma melhor formação do aluno. Considerando os dados dos Planos de Atendimento Consolidados de 2016 a 2018 do PNME em Belterra/PA, evidenciamos que atividades foram trabalhadas de acordo com o seu macrocampo:

a) Escolas da Zona Urbana: Acompanhamento pedagógico (Língua Portuguesa, Matemática); Esporte e Lazer (Futebol, Voleibol e basquete); Cultura e Artes (Iniciação Musical/banda/ Canto coral e dança).

b) Escolas da Zona Rural: Acompanhamento pedagógico (Língua portuguesa, Matemática); Esporte e Lazer: (Futebol, Voleibol e Capoeira); Cultura e Artes (Iniciação Musical/banda/ Canto coral, dança, Educação patrimonial, Artesanato e Cine clube).

0 currículo do PNME é constituído a partir da carga horária escolhida pela instituição escolar podendo optar entre a carga horaria de $5 \mathrm{~h}$ ou a de $15 \mathrm{~h}$, ambas semanais. 0 currículo para as escolas que escolherem trabalhar semanalmente com 5 horas é composto apenas pelo acompanhamento pedagógico da Língua portuguesa e Matemática. Em Belterra somente duas escolas aderiram as 5 horas do programa, onde no início do programa do ano vigente, o mediador identifica em conjunto com o professor de sala de aula, quais alunos devem participar do PNME, desde que estejam em consonância do perfil do programa, que estão com dificuldades de aprendizagem em relação as disciplinas de Português e Matemática.

As aulas do acompanhamento pedagógico ocorriam em 2 dias da semana, onde cada dia era destinado ao PNME $2 \mathrm{~h}$ e $30 \mathrm{~min}$ (dividida em dois momentos: Primeiramente, iniciava com atividades de Língua Portuguesa ou Matemática com duração de 1 h e $15 \mathrm{~min}$. $\mathrm{E}$ a mesma duração da atividade anterior era disponibilizada para contemplar outra disciplina restante, sendo que no outro dia de aula complementar havia uma inversão na ordem 
das disciplinas), em que os mediadores trabalhavam por meio de atividades lúdicas (jogos pedagógicos) as principais dificuldades dos alunos, adequando o conteúdo abordado ao que está sendo repassado em sala de aula pelo professor, formando turmas o mais homogêneas possiveis em termos de série escolar, para que consiga instruir e dar suporte aos alunos do programa de forma a otimizar esse tempo complementar de ensino.

As escolas que optaram por trabalhar com carga horária de 15 horas, além de contemplar o acompanhamento pedagógico da Língua portuguesa e Matemática (destinando para cada uma delas 4 horas semanais) que é obrigatório, devem integrar a esse currículo atividades que compõem os macrocampos, Esporte e Lazer, Cultura e Artes $(7$ horas semanais para essas atividades).

Conforme o Plano de Atendimento de adesão ao PNME 2016, as escolas deveriam selecionar as atividades obrigatórias (Língua Portuguesa e Matemática) e mais 3 atividades disponiveis nos outros macrocampos. Essas 3 atividades complementares foram escolhidas pelas instituições escolares de Belterra da seguinte forma: 1 do macrocampo Esporte e Lazer, e 2 do macrocampo Cultura e Artes,

As escolas da zona urbana de Belterra focaram suas atividades complementares em duas modalidades de esporte, voleibol e futebol, atividades que são frequentes entre moradores desse município de diferentes faixas etárias, em relação as atividades de cultura e artes, houve em todas as escolas a inserção da iniciação musical/fanfarra/coral, como forma de aprimorar os ensaios da fanfarra escolar, que se prepara anualmente para apresentarse no tradicional desfile de 7 de setembro no centro de Belterra e em outras ocasiões comemorativas. Nas escolas da zona rural as atividades relacionadas a Cultura e Artes estão mais voltadas para a artesanato e dança, e no macrocampo Esporte e lazer, além do futebol e voleibol, houve a opção de uma escola trabalhar com capoeira.

Para que os mediadores e facilitadores trabalhassem de maneira a contribuir com o desempenho escolar dos alunos, houveram formações para os coordenadores municipais do programa, em que tiveram a oportunidade de compreender como a utilização de uma sequência didática ${ }^{8}$ para nortear a aplicação intencional das atividades poderia favorecer um processo de aprendizagem dos participantes do programa. As coordenadoras participaram de uma formação para os integrantes que trabalhariam com o PNME, em que repassaram as informações obtidas na formação regional do programa, propondo metodologias que poderiam servir de base para a aplicação das atividades. Essa sequência didática ocorreu da seguinte maneira: os mediadores e facilitadores trabalhavam bimestralmente um tema, e articulava com diferentes conteúdos das disciplinas do currículo regular. Exemplo, no primeiro semestre de

8 De acordo com Araújo (2013, p. 322-323) sequência didática (doravante SD) é um modo de o professor organizar as atividades de ensino em função de núcleos temáticos e procedimentais. 
2017 em todas as escolas foi trabalhado com o Tangram, $^{9}$ e a partir desse recurso houve a possibilidades de trabalhar a Língua Portuguesa na composição de palavras, texto, etc., na matemática, as formas geométricas, as 4 operações (adição, subtração, multiplicação e divisão), etc., na história, o surgimento do Tangram, diversas possibilidades, mas sempre adequando ao nível de escolaridade dos educandos.

Para que essas atividades que compõem os programas indutores de Educação Integral (PME e PNME) consigam oportunizar aos seus alunos uma ampliação de conhecimentos, torna-se necessário também ampliar os tempos e espaços de formação. É nessa perspectiva de considerar relevante a integração entre currículo e espaço que expomos a seguir, sobre os espaços utilizados pelas escolas de Belterra para desenvolverem as atividades do PME e PNME.

\subsection{A INFRAESTRUTURA NA EDUCAÇÃO INTEGRAL}

Para Cavalieri (2007) as Instituições escolares devem proporcionar aos alunos condições favoráveis para vivenciarem experiências de compartilhamento e reflexão, a fim de prepará-los para uma vida democrática, e isso requer, sobretudo, pensar em uma infraestrutura para além dos espaços, considerando a organização do tempo. Nessa perspectiva, apresentamos os espaços utilizados pelo PME e PNME nas escolas municipais de Belterra, assim como a organização do tempo para a efetivação desses programas.

\subsubsection{Espaços}

A preocupação para a implementação do Programa Mais Educação no município de Belterra era em relação aos espaços que serviriam para a realização de suas oficinas, pois as escolas tinham estruturas físicas limitadas, sem muitos ambientes escolares adequados que servissem de suporte para a realização de atividades como o acompanhamento pedagógico, já que a prioridade sempre foi a construção de sala de aula, ocasionando a ocupação de biblioteca, sala de informática, entre outros, para essa finalidade.

9 Conforme Macedo et al. (2015) Tangram é um jogo chinês, tipo quebra cabeça, composto por sete peças: cinco triângulos (dois grandes, um médio e dois pequenos) um quadrado e um paralelogramo, ambos com área equivalente aos dois triângulos pequenos ou ao médio, que tem por finalidade organizar, sem sobrepor umas às outras, todas as sete peças de modo correspondente a uma figura que serve como modelo ou referência. 
A quarta estratégia da Meta 6 do Plano Nacional de Educação (2014/2024) estimula "a articulação da escola com os diferentes espaços educativos, culturais e esportivos e com equipamentos públicos, como centros comunitários, bibliotecas, praças, parques, museus, teatros, cinemas e planetários." (BRASIL, 2014, p. 42).

As escolas que aderiram ao PME e possuíam quadra esportiva em seu ambiente físico, usavam-na para desenvolver todas as oficinas do PME, inclusive o acompanhamento pedagógico. Em uma das escolas que não tinha quadra esportiva e nem salas disponíveis para realizarem as atividades desse programa, conseguiram por meio de uma parceria com a comunidade local, a permissão para realizarem as oficinas do PME no barracão comunitário.

Em contrapartida a concessão do barracão comunitário para essa escola, a comunidade pediu que a equipe de profissionais que trabalhasse como oficineiro nesse programa fosse composta por seus moradores, e que para pleitearem uma vaga deveriam ter algum tipo de qualificação para ministrarem tais atividades, o que implicou diretamente nas escolhas das atividades selecionadas pela escola na plataforma do PME.

A seleção dos alunos que participaram do PME, que em sua maioria foi composto por discentes que residiam próximo ao local onde eram realizadas as atividades, ou que se deslocassem por conta própria através de bicicleta ou motocicleta (transportes mais utilizados pelos moradores para se locomoverem na cidade), tendo em vista que o município não conta com frota urbana de ônibus que circule por seus bairros.

A adesão ao Programa Novo Mais Educação se deu no final de 2016 e começou a ser efetivado nas escolas municipais de Belterra no primeiro semestre de 2017 (BRASIL, 2016b). Das 7 escolas que aderiram ao programa Novo Mais Educação, apenas duas escolheram a carga horária de 5 horas/semanais, dividindo $2 \mathrm{~h}$ e $30 \mathrm{~min}$ para cada disciplina (Língua Portuguesa e Matemática), e utilizaram o refeitório da escola (antes e depois do horário destinado ao recreio) para realizarem o acompanhamento pedagógico.

As demais escolas que optaram por 15 horas/semanais também realizavam o acompanhamento dentro da escola como refeitório, corredores, biblioteca ou sala de informática (caso essas duas últimas não tenham sido transformadas em sala de aula) para fazerem o acompanhamento pedagógico correspondente às 8 horas/semanais, e às 7 horas restantes destinadas ao Esporte e Lazer, Cultura e Arte, foram efetivadas em suas quadras esportivas ou usavam a quadra ou campo de futebol pertencente a comunidade local.

Para Arroyo (2012, p. 44) é de suma relevância "dar maior centralidade à construção de espaços escolares públicos dignos" para subsidiar esses programas. E mesmo as escolas que não dispunham de espaços adequados dentro seu ambiente escolar para a implementação de programas que demandam um mínimo de infraestrutura física, 
como algumas escolas municipais de Belterra conseguiram fazer do seu entorno um lugar socializador de aprendizagens.

Portanto, de acordo com Cavalieri (2007) uma Educação em Tempo Integral, independe de uma estruturação de uma escola que contemple uma ampliação da permanência do aluno somente em seu espaço físico, mas que agregue outros ambientes e colaboradores, emergindo assim uma concepção multissetorial de Educação Integral.

Entretanto, Jacomeli, Barão e Gonçalves (2018) ressaltam que essa lógica organizativa de educação, desvirtua o papel da escola como promovedora de formação científica e cultural, tendo em vista que acaba por "desresponsabilizar o Estado de suas obrigações constitucionais de financiamento e garantia de padrão de qualidade na educação pública, já que se joga para as parcerias e para o âmbito local a responsabilidade pelo insucesso de instrumentalização do alunado." (JACOMELI; BARÃO; GONÇALVES, 2018, p. 53). Como as atividades do PME e PNME eram feitas no contraturno escolar, tornou-se necessário a organização do tempo escolar para possibilitar tais atividades complementares.

\subsubsection{Organização do tempo}

0 tempo apresenta-se como um fator imprescindivel para o desenvolvimento pleno do estudante, considerando principalmente o tempo qualitativamente transformado, e não somente seus aspectos quantitativos, pois "a extensão do horário deve construir o tempo qualitativo dentro da escola, ou sob sua supervisão, e, nesse sentido, esse tempo qualitativo pressupõe uma formação mais completa para o ser humano-cidadão-aluno." (COELHO, 2009, p. 93).

0 PME ocorria no contraturno, onde cada escola ficava responsável por organizar seu cronograma de atividades considerando a disponibilidade do espaço utilizado e dos profissionais que ministravam as oficinas. Com base em um cronograma de uma escola municipal de Belterra que aderiu ao PME, podemos verificar a organização do tempo destinado a esse programa. 
Política indutora de educação...

Quadro 1 - Cronograma de atividades do Programa Mais Educação de uma escola municipal de Belterra (2012/2015)

\begin{tabular}{|l|l|l|l|l|l|}
\hline \multirow{2}{*}{ HORÁRIO } & \multicolumn{5}{|c|}{ TURMA “A” (MATUTINO) } \\
\cline { 2 - 6 } & \multicolumn{1}{|c|}{ Segunda } & \multicolumn{1}{|c|}{ Terça } & \multicolumn{1}{c|}{ Quarta } & \multicolumn{1}{c|}{ Quinta } & Sexta \\
\hline $\begin{array}{l}\text { 07:00 às } \\
08: 30\end{array}$ & Brinquedoteca & $\begin{array}{l}\text { Agroecologia } \\
\text { (Canteiro susten- } \\
\text { tável) }\end{array}$ & $\begin{array}{l}\text { Brinquedoteca } \\
\text { (Canteiro susten- } \\
\text { tável) }\end{array}$ & $\begin{array}{l}\text { Sistema de } \\
\text { Revezamento }\end{array}$ \\
\hline $\begin{array}{l}\text { 08:30 às } \\
08: 45\end{array}$ & Lanche & Lanche & Lanche & Lanche & Lanche \\
\hline $\begin{array}{l}\text { 08:45 às } \\
\text { 10:00 }\end{array}$ & $\begin{array}{l}\text { Acompanhamen- } \\
\text { to Pedagógico } \\
\text { (Letramento e } \\
\text { Alfabetização) }\end{array}$ & Futebol & $\begin{array}{l}\text { Acompanhamen- } \\
\text { to Pedagógico } \\
\text { (Matemática) }\end{array}$ & Futebol & Sistema de \\
\hline
\end{tabular}

Fonte: Plano de Ação do PME de uma Escola municipal de Belterra/PA, 2012.

Quadro 2 - Cronograma de atividades do PME de uma escola municipal de Belterra (2012/2015)

\begin{tabular}{|c|c|c|c|c|c|}
\hline \multirow{2}{*}{ HORÁRIO } & \multicolumn{5}{|c|}{ TURMAS “B” e “C” (VESPERTINO) } \\
\hline & Segunda & Terça & Quarta & Quinta & Sexta \\
\hline \multirow{2}{*}{$\begin{array}{l}13: 30 \text { às } \\
14: 45\end{array}$} & $\begin{array}{l}\text { Acompanhamento } \\
\text { Pedagógico (Letra- } \\
\text { mento e Alfabetiza- } \\
\text { ção) Turma B }\end{array}$ & $\begin{array}{l}\text { Agroecologia } \\
\text { (Canteiro susten- } \\
\text { tável) Turma B }\end{array}$ & $\begin{array}{l}\text { Brinquedoteca } \\
\text { (Turma B) }\end{array}$ & Futebol (Turma B) & \multirow{2}{*}{$\begin{array}{l}\text { Sistema de } \\
\text { Reveza- } \\
\text { mento }\end{array}$} \\
\hline & $\begin{array}{l}\text { Brinquedoteca } \\
\text { (Turma C) }\end{array}$ & Futebol (Turma C) & $\begin{array}{l}\text { Acompanhamento } \\
\text { Pedagógico (Mate- } \\
\text { mática) Turma C }\end{array}$ & $\begin{array}{l}\text { Agroecologia } \\
\text { (Canteiro susten- } \\
\text { tável) Turma C }\end{array}$ & \\
\hline $\begin{array}{l}14: 45 \text { às } \\
15: 00\end{array}$ & Lanche & Lanche & Lanche & Lanche & Lanche \\
\hline \multirow{2}{*}{$\begin{array}{l}15: 00 \text { às } \\
16: 30\end{array}$} & $\begin{array}{l}\text { Brinquedoteca } \\
\text { (Turma B) }\end{array}$ & Futebol (Turma B) & $\begin{array}{l}\text { Acompanhamento } \\
\text { Pedagógico (Mate- } \\
\text { mática) Turma B }\end{array}$ & $\begin{array}{l}\text { Agroecologia } \\
\text { (Canteiro susten- } \\
\text { tável) Turma B }\end{array}$ & \multirow{2}{*}{$\begin{array}{l}\text { Sistema de } \\
\text { Reveza- } \\
\text { mento }\end{array}$} \\
\hline & $\begin{array}{l}\text { Acompanhamento } \\
\text { Pedagógico (Letra- } \\
\text { mento e Alfabetiza- } \\
\text { ção) Turma C }\end{array}$ & $\begin{array}{l}\text { Agroecologia } \\
\text { (Canteiro susten- } \\
\text { tável) Turma C }\end{array}$ & $\begin{array}{l}\text { Brinquedoteca } \\
\text { (Turma C) }\end{array}$ & Futebol (Turma C) & \\
\hline
\end{tabular}

Fonte: Plano de Ação do PME de uma Escola municipal de Belterra/PA, 2012.

Considerando os dados dos Quadros 1 e 2, de segunda-feira à quinta-feira havia a oferta de duas disciplinas por dia para todas as turmas com intervalo para o lanche, e na sexta-feira era adotado o sistema de revezamento, no qual consistem em dividir as turmas em grupos menores, já que nesse dia as quatro atividades eram ofertadas, sendo que duas atividades aconteciam de forma simultânea. 
No programa Novo Mais Educação, as atividades também foram realizadas no contraturno escolar, entretanto, havia uma diferença entre a organização do tempo, haja vista que esse programa disponibilizou dois tipos de carga horária/semanal para as escolas aderirem. Segundo o Documento Orientador do PNME (2016) as escolas que aderiram as 5 horas semanais têm autonomia para a organização do tempo escolar, entretanto, para as escolas que decidiram pela carga horária semanal de 15 horas, esse documento faz algumas sugestões quanto a organização das atividades complementares no campo da Arte, Cultura, Esporte e Lazer (BRASIL, 2016).

Nos Quadros 3 e 4, apresentamos o cronograma semanal de uma escola municipal de Belterra/PA que aderiu a carga horária de 15h, na qual agregou ao Acompanhamento Pedagógico (8 horas semanais divididas igualmente entre Língua portuguesa e Matemática) mais 2 atividades do macrocampo Esporte, Lazer, Cultura e Arte (com carga horária total de 7 horas semanais).

Quadro 3 - Cronograma de atividades do PNME de uma escola municipal de Belterra (2017/2018)

\begin{tabular}{|c|c|c|c|c|c|}
\hline \multirow{2}{*}{ HORÁRIO } & \multicolumn{5}{|c|}{ TURMAS “A” e "B” (MANHÃ) } \\
\hline & Segunda & Terça & Quarta & Quinta & Sexta \\
\hline \multirow{2}{*}{$\begin{array}{l}07: 30 \text { d̀s } \\
09: 30\end{array}$} & $\begin{array}{l}\text { Lingua Portuguesa } \\
\text { (Turma A) }\end{array}$ & $\begin{array}{l}\text { Lingua Portuguesa } \\
\text { (Turma A) }\end{array}$ & \multirow{2}{*}{$\begin{array}{l}\text { Música } \\
\text { (Turma A) }\end{array}$} & \multirow{2}{*}{$\begin{array}{l}\text { Música } \\
\text { (Turma A) }\end{array}$} & \multirow{2}{*}{$\begin{array}{l}\text { Futebol } \\
\text { (Turma A) }\end{array}$} \\
\hline & $\begin{array}{l}\text { Matemática } \\
\text { (Turma B) }\end{array}$ & $\begin{array}{l}\text { Matemática } \\
\text { (Turma B) }\end{array}$ & & & \\
\hline $\begin{array}{l}09: 30 \text { às } \\
09: 45\end{array}$ & Lanche & Lanche & Lanche & Lanche & Lanche \\
\hline \multirow{2}{*}{$\begin{array}{l}\text { 09:45 às } \\
11: 30\end{array}$} & $\begin{array}{l}\text { Lingua Portuguesa } \\
\text { (Turma B) }\end{array}$ & $\begin{array}{l}\text { Lingua Portuguesa } \\
\text { (Turma B) }\end{array}$ & \multirow{2}{*}{$\begin{array}{l}\text { Música } \\
\text { (Turma B) }\end{array}$} & \multirow{2}{*}{$\begin{array}{l}\text { Música } \\
\text { (Turma B) }\end{array}$} & \multirow{2}{*}{$\begin{array}{l}\text { Futebol } \\
\text { (Turma B) }\end{array}$} \\
\hline & $\begin{array}{l}\text { Matemática } \\
\text { (Turma A) }\end{array}$ & $\begin{array}{l}\text { Matemática } \\
\text { (Turma A) }\end{array}$ & & & \\
\hline
\end{tabular}

Fonte: Plano de Ação do PNME de uma Escola municipal de Belterra/PA, 2017.

Quadro 4 - Cronograma de atividades do PNME de uma escola municipal de Belterra (2017/2018)

\begin{tabular}{|c|c|c|c|c|c|}
\hline \multirow{2}{*}{ HORÁRIO } & \multicolumn{5}{|c|}{ TURMAS “C" e "D" (TARDE) } \\
\hline & Segunda & Terça & Quarta & Quinta & Sexta \\
\hline \multirow{2}{*}{$\begin{array}{l}13: 30 \text { às } \\
15: 30\end{array}$} & \multirow{2}{*}{ Futebol (Turma C) } & $\begin{array}{l}\text { Lingua Portuguesa } \\
\text { (Turma C) }\end{array}$ & $\begin{array}{l}\text { Língua Portuguesa } \\
\text { (Turma C) }\end{array}$ & \multirow{2}{*}{$\begin{array}{l}\text { Música } \\
\text { (Turma C) }\end{array}$} & \multirow{2}{*}{$\begin{array}{l}\text { Música } \\
\text { (Turma C) }\end{array}$} \\
\hline & & $\begin{array}{l}\text { Matemática } \\
\text { (Turma D) }\end{array}$ & $\begin{array}{l}\text { Matemática } \\
\text { (Turma D) }\end{array}$ & & \\
\hline $\begin{array}{l}15: 30 \text { às } \\
15: 45\end{array}$ & Lanche & Lanche & Lanche & Lanche & Lanche \\
\hline
\end{tabular}


Política indutora de educação...

\begin{tabular}{|l|l|l|l|l|l|}
\hline \multirow{2}{*}{ HORÁRIO } & \multicolumn{5}{|c|}{ TURMAS “C” e “D” (TARDE) } \\
\cline { 2 - 5 } & \multicolumn{1}{|c|}{ Segunda } & \multicolumn{1}{|c|}{ Terça } & \multicolumn{1}{c|}{ Quarta } & \multicolumn{1}{c|}{ Quinta } & \multicolumn{1}{c|}{ Sexta } \\
\hline \multirow{3}{*}{$\begin{array}{l}15: 45 \text { às } \\
17: 30\end{array}$} & \multirow{3}{*}{ Futebol (Turma D) } & $\begin{array}{l}\text { Língua Portuguesa } \\
\text { (Turma D) }\end{array}$ & $\begin{array}{l}\text { Língua Portuguesa } \\
\text { (Turma D) }\end{array}$ & Música & Música \\
\cline { 3 - 4 } & & $\begin{array}{l}\text { Matemática } \\
\text { (Turma D) }\end{array}$ & (Turma D) \\
& & $\begin{array}{l}\text { Matemática } \\
\text { (Turma C) }\end{array}$ & & \\
\hline
\end{tabular}

Fonte: Plano de Ação do PNME de uma Escola municipal de Belterra/PA, 2017.

Os Quadros 3 e 4 demonstram como foi organizado o tempo destinado a uma escola que aderiu a 15 horas/semanais, no qual as atividades que complementaram as 7 horas/semanais foram Futebol e Música. As demais escolas que também utilizaram esse formato de carga horária puderam escolher duas atividades do campo: Arte, Cultura, Esporte e Lazer, além do acompanhamento Pedagógico que é obrigatório.

Para que não haja paralização das atividades do Novo Mais Educação, como ocorreu em 2016 no PME, é necessário que o governo Federal, como fomentador desse programa por meio do PDDE/Educação Integral, não cesse a liberação de recursos destinados ao PNME. Diante disso, apresentamos como se deu a capitação de recurso para a implementação dos programas indutores de Educação Integral na rede municipal de Belterra/PA.

\subsubsection{O financiamento do PME e PNME}

0 financiamento é parte integrante do processo de implementação dos Programas de Educação Integral, haja vista que a Lei 11.494/2007, estabelece recursos diferenciados para as escolas que aderissem à jornada escolar superior a 7 horas diárias. Nessa perspectiva, Ferreira (2016, p. 64) esclarece que esses valores recebidos pelos programas se dão pelas "dificuldades financeiras de construção ou ampliação de escolas para o atendimento em tempo integral, que obviamente demandam investimentos vultosos, não só na etapa inicial, mas também para sua manutenção."

A Educação Integral efetivou-se em Belterra por meio do PME em 2012, onde 11 escolas conseguiram enquadrar-se nos critérios estabelecidos para a adesão ao programa. 0 primeiro recurso recebido, conforme demonstra a Tabela 2, ocorreu no final do segundo semestre de 2012, o que possibilitou o imediato início das atividades desse programa em agosto de 2012. Veremos, também no quadro citado, como foi feito o repasse dos recursos referentes ao PME que ocorreu em Belterra/PA de 2012 a 2015. 
Tabela 2 - Valores recebidos pelas escolas no ano de exercício do PME

\begin{tabular}{|c|c|c|c|c|c|}
\hline Ano exercício & & $\begin{array}{l}\text { de } \\
\text { olas }\end{array}$ & $\begin{array}{c}\text { Data de } \\
\text { pagamento }\end{array}$ & Programa & $\begin{array}{l}\text { Recurso } \\
\text { Total (R\$) }\end{array}$ \\
\hline \multirow{2}{*}{2012} & \multirow{2}{*}{1} & 11 & $30 / 07 / 2012$ & Mais Educação-PDDE INTEGRAL & $284.730,60$ \\
\hline & & 09 & 06/12/2012 & Mais Educação-PDDE INTEGRAL-complemento & $2.673,00$ \\
\hline \multirow{2}{*}{2013} & \multirow{2}{*}{19} & 1 & $30 / 04 / 2013$ & Mais Educação-PDDE / 2ª parc. 2012 & $87.840,00$ \\
\hline & & 19 & $29 / 11 / 2013$ & Mais Educação-PDDE INTEGRAL & $516.374,03$ \\
\hline \multirow{2}{*}{2014} & \multirow{2}{*}{17} & 17 & 03/07/2014 & Mais Educação-PDDE $/ /^{a}$ parc. 2014 & $334.800,00$ \\
\hline & & 03 & $26 / 09 / 2014$ & Mais Educação-PDDE-complemento/1ª parc. 2014 & $2.000,02$ \\
\hline 2015 & 01 & & $18 / 06 / 2015$ & Mais Educação-PDDE / $2^{a}$ parc. 2014 & $17.150,00$ \\
\hline
\end{tabular}

Fonte: adaptada de Brasil [2017?].

Em 2015 conforme a Tabela 2 apenas uma escola permaneceu com atividades do PME, e isso aconteceu pois cumpriu os 10 meses de atividade em 2014, prestando conta do uso total do recurso, conseguindo, portanto, ser contemplada com a $2^{a}$ parcela referente a 2014, paga ao final do $1^{\circ}$ semestre de 2015. Também salientamos que a reprogramação do PME por algumas escolas, ocasionou os atrasos dos recursos, uma vez que as escolas ao receber o recurso para a compra de materiais e de custeio do programa tinham 10 meses para a efetivação das atividades no qual deveriam utilizar nesse período todo o dinheiro proveniente do PME, sendo que em dezembro era feita a prestação de contas e a adesão das escolas para o ano seguinte, através de um relatório e formulário disponibilizado no portal do Ministério da Educação (MEC).

Segundo o documento norteador Manual operacional de Educação Integral (2013), os profissionais responsáveis pela implementação do PME nos municípios eram o coordenador do programa, o professor comunitário e os monitores ou oficineiros. Tanto o coordenador do programa quanto o professor comunitário deveriam ser servidores efetivos da Secretaria de educação, estadual ou municipal, pois estes não recebiam qualquer bônus pelo seu trabalho no programa.

Como a atividade desempenhada pelos monitores era de natureza voluntária, ${ }^{10}$ o programa pagava somente um valor correspondente ao transporte e alimentação desses profissionais, e o valor final deveria considerar a quantidade de turmas, podendo ser várias (dependendo da disponibilidade do monitor sem prejuízo das demais turmas, sendo autorizado a ministração simultânea, somente para duas turmas do acompanhamento pedagógico) e a

100 Manual Operacional de Educação Integral (BRASL, 2013) ratifica que a Lei $n^{\circ} 9.608$, de 18 de fevereiro de 1998, que regulamenta o trabalho voluntário determina que seja obrigatória a celebração do Termo de Adesão e Compromisso do Voluntário sem qualquer ressarcimento de valores pelos serviços prestados. 
zona (urbana e rural) em que a escola estava localizada, conforme podemos verificar na Tabela 3.

Tabela 3 - Valor pago aos monitores de acordo com a quantidade de turmas e a zona em que está situada a escola

\begin{tabular}{llr}
\hline \multicolumn{1}{c}{ Escolas por zona } & Quantidade de turmas & \multicolumn{2}{c}{ Valor (R\$) } \\
\hline Urbana & 1 & 80,00 \\
Rural & 1 & 120,00 \\
\hline
\end{tabular}

Fonte: Brasil (2013, p. 24).

$\mathrm{Na}$ Tabela 3, fica evidente que os monitores que trabalhavam na zona rural recebiam $50 \%$ a mais do que os monitores da zona urbana. Segundo o Manual Operacional de Educação Integral (BRASIL, 2013, p. 25), essa maior bonificação para os monitores que trabalhavam na zona rural caracterizava-se como estratégia para incentivar a oferta de uma educação adequada ao modo de viver, pensar e produzir das populações que residem no campo firmando-o "como o lugar onde vivem sujeitos de direitos, com diferentes dinâmicas de trabalho, de cultura, de relações sociais, e não apenas como um espaço que meramente reproduz os valores do desenvolvimento urbano."

Os recursos destinados ao programa proveniente do PDDE/Integral, de acordo com o Manual Operacional de Educação Integral (BRASIL, 2013), eram destinados para o custeio com a manutenção do PME e a formação do seu capital, sendo caracterizados da seguinte forma:

\footnotetext{
Custeio: - Ressarcimento com as despesas de transporte e alimentação dos monitores responsáveis pelo desenvolvimento das atividades; · Aquisição dos materiais pedagógicos necessários as atividades, conforme os kits sugeridos; - Aquisição de outros materiais de consumo e/ou contratação de serviços necessários ao desenvolvimento das atividades de educação Integral. Capital: • Aquisição de bens ou materiais, de acordo com os kits sugeridos, além de outros bens permanentes necessários ao desenvolvimento das atividades. (BRASIL, 2013).
}

Na Tabela 4, podemos entender como era realizado o cálculo para o repasse de verbas referentes ao custeio e capital para as escolas levando em consideração o número de alunos inscritos no PME. 
Tabela 4 - Valor do repasse para as escolas em custeio e capital considerando o $\mathrm{n}^{\circ}$ de alunos

\begin{tabular}{llr}
\hline Números de alunos & Valor em custeio (R\$) & Valor em capital (R\$) \\
\hline Até 500 & $3.000,00$ & $1.000,00$ \\
501 a 1.000 & $6.000,00$ & $2.000,00$ \\
Mais de 1.000 & $7.000,00$ & $2.000,00$ \\
\hline
\end{tabular}

Fonte: Brasil (2013, p. 24).

Em relação à alimentação escolar, a Resolução n 67 de 28 de dezembro de 2009 do Programa Nacional de Alimentação Escolar - PNAE destinava às Secretarias Estaduais e Distrital de Educação e às Prefeituras Municipais, que tem alunos participando do Programa Mais Educação o valor de R\$ 0,90 (noventa centavos de real) por aluno, como forma de subsidiar a alimentação a mais que esses alunos tem direito (BRASIL, 2009). Os alunos participantes do PME tinham por direito receber 3 refeições diárias conforme determinou o Inciso VI da Resolução CD/FNDE n² 26, de 17 de junho de 2013, sendo fornecida "no mínimo 70\% (setenta por cento) das necessidades nutricionais, distribuídas em, no mínimo, três refeições, para os alunos participantes do Programa Mais Educação e para os matriculados em escolas de tempo integral." (BRASIL, 2013).

Mediante a Tabela 5 verificamos quais os valores recebidos entre 2012 e 2015 pelo município de Belterra referente a merenda escolar destinada aos alunos do Programa Mais Educação.

Tabela 5 - Recurso do PNAE destinado ao PME (2012 a 2015)

\begin{tabular}{cccr}
\hline 2012 & 2013 & 2014 & 2015 \\
\hline$R \$ 56.040,00$ & $R \$ 100.872,00$ & $R \$ 52.680,00$ & $R \$ 96.648,00$ \\
\hline
\end{tabular}

Fonte: adaptada de Brasil [2017?].

Identificamos que em 2015 houve o repasse para a complementação da alimentação escolar das escolas que estavam inscritas no censo escolar de 2014 como participantes do PME, mesmo esse programa tendo suas atividades paralisadas a partir do segundo semestre de 2015, por falta de repasse do governo para a remuneração dos oficineiros.

A adesão ao PNME das escolas municipais de Belterra aconteceu no último semestre de 2016, e no final de dezembro desse ano foram transferidos os recursos referentes a $1^{a}$ parcela de 2016, ainda no site do PDDE-Educação Integral com o nome de Mais Educação" fazendo com que as atividades do programa fossem reprogramadas para 2017 ,

" Como o programa havia trocado de nome recentemente, o site supracitado continuava a descrevê-lo como Mais Educação. Entretanto, já estava sendo aplicado nas escolas o Novo Mais Educação. 
e em meados do $2^{\circ}$ semestre de 2017 foram depositados os recursos da $2^{\circ}$ parcela de 2016 , como está disposto no Tabela 6.

Tabela 6 - Valores recebidos pelas escolas correspondentes ao PNME 2018

\begin{tabular}{|c|c|c|c|c|c|}
\hline Ano exercício & $\mathrm{N}^{\circ}$ de escolas & & $\begin{array}{l}\text { Data de paga- } \\
\text { mento }\end{array}$ & Programa & Recurso Total (R\$) \\
\hline 2016 & & 7 & 28/12/2016 & $\begin{array}{l}\text { Mais Educação-PDDE / 1` parc. } \\
2016\end{array}$ & $108.987,00$ \\
\hline 2017 & & 7 & 22/09/2017 & $\begin{array}{l}\text { Mais Educação-PDDE / } 2^{a} \\
\text { parc. } 2016\end{array}$ & $72.660,00$ \\
\hline \multirow{4}{*}{2018} & \multirow{4}{*}{8} & 1 & 18/04/2018 & $\begin{array}{l}\text { Novo Mais Educação-PDDE } / 1^{\circ} \\
\text { parc. } 2018\end{array}$ & $16.452,00$ \\
\hline & & 1 & १८/06/2018 & $\begin{array}{l}\text { Novo Mais Educação-PDDE / }{ }^{\circ} \\
\text { parc. } 2018\end{array}$ & $16.452,00$ \\
\hline & & 2 & $17 / 10 / 2018$ & $\begin{array}{l}\text { Novo Mais Educação-PDDE /2a } \\
\text { parc. } 2018\end{array}$ & $21.936,00$ \\
\hline & & 6 & 26/12/2018 & $\begin{array}{l}\text { Novo Mais Educação-PDDE /1a } \\
\text { parc. } 2018\end{array}$ & $71.280,00$ \\
\hline
\end{tabular}

Fonte: adaptada de Brasil [2017?].

Destacamos na Tabela 6 que algumas parcelas referentes ao ano de exercício do programa, eram depositadas apenas ao final do seu ano letivo, impossibilitando dessa forma a execução das atividades. Ainda podemos verificar nesse quadro, que em 2018, das 8 escolas inseridas no PNME, somente duas escolas receberam 2 parcelas do PDDE, e por isso iniciaram suas atividades em 2018, e as 6 escolas restantes tiveram que reprogramar suas atividades para 2019, porque o recurso foi transferido somente ao final de 2018. Percebemos que o ato recorrente nas escolas de reprogramação dessas atividades, incide no descompromisso com o programa, não levando em conta o prejuízo que essa postergação pode ocasionar no processo de ensino-aprendizagem de seus alunos.

Para a implementação do PNME se fez necessário montar uma rede de colaboradores (Coordenador, Articulador, Mediador e Facilitador) para ajudar na execução e manutenção do programa. A seguir, descrevemos como cada colaborador do PNME era remunerado:

a) coordenador: como o PNME prioriza o trabalho voluntário, não há valores destinados para a atuação do Coordenador do programa, por isso ele deve ser um profissional efetivo; 
b) articulador: assim como o coordenador, o articulador não terá vencimentos pelo seu trabalho no PNME, também devendo ser um profissional efetivo;

c) mediador: os valores recebidos são referentes à ajuda de custos para transporte e alimentação, $\mathrm{R} \$ 150,00$ por mês, por turma de acompanhamento pedagógico, para escolas urbanas com carga horaria de 15 (quinze) horas, e $\mathrm{R} \$ 80,00$ por mês, por turma de acompanhamento pedagógico, para escolas urbanas com carga horária de 5 (cinco) horas, sendo que as escolas rurais tem um acréscimo de $50 \%$ sobre esses valores. Cada mediador poderá acumular até 10 turmas;

d) facilitador: como trabalho voluntário, receberá para os custeios do transporte e alimentação, sendo $R \$ 80,00$ por mês, por turma das atividades de livre escolha da escola, para escolas urbanas que implementarem carga horária complementar de 15 (quinze) horas, e nas escolas rurais é pago $50 \%$ a mais. E esse profissional poderá trabalhar em até 10 turmas.

Em relação à alimentação escolar do PMNE, a resolução CD/FNDE $n^{\circ}$ 1/2017 (BRASIL, 2017) alterou os valores per capita para os programas indutores de educação integral que estavam dispostos na resolução CD/FNDE n²6/2013, o qual determina que "para os estudantes do Programa Novo Mais Educação haverá complementação financeira de forma a totalizar o valor per capita de R\$1,07 (um real e sete centavos)." Na Tabela 7 identificamos os valores que foram recebidos pelo município de Belterra para a complementação da alimentação escolar ofertada aos alunos que participaram do programa de 2016 a 2018.

Tabela 7 - Recurso do PNAE destinado ao PNME (2016 a 2018)

\begin{tabular}{llll}
\hline & & 2016 & 2018 \\
\hline$R \$ 109.680,00$ & $R \$ 78.838,40$ & $R \$ 22.720,00$ & \\
\hline
\end{tabular}

Fonte: adaptada de Brasil [2017?].

Em 2016, 2017 e 2018 eram 7, 7, e 8 escolas, respectivamente, que integraram o PNME e dessas somente duas escolas não aderiram a carga horária de 15 horas semanais, portanto, as demais receberam recurso para ofertar aos alunos participantes desse programa 3 refeições diárias, pois enquadram-se na jornada escolar superior de 7 horas diárias, estabelecida pela Resolução CD/FNDE n²6, de 17/06/2013. Entretanto, as escolas tanto às de 5 horas/semanais quanto às de 15 horas/semanais ofertavam somente o lanche nos intervalos das atividades do contraturno. Podemos ainda identificar nesse quadro que 
apesar de não haver uma discrepância entre o quantitativo de escolas participantes do PNME nos anos de 2016, 2017 e 2018, nota-se que os valores foram bem distintos entre eles.

Evidenciamos que além do PDDE/Educação Integral não houve outras parcerias públicas ou privadas para subsidiar o PME e PNME. Nesse sentido, Mauricio (2016) enfatiza que muitas escolas mesmo não possuindo infraestrutura adequada, aderem a programas como - PME e o PNME, como forma de garantir recursos para transformarem seus ambientes e diminuir a precariedade escolar.

\section{CONSIDERAÇŌES FINAIS}

Educação Integral é um direito constitucional de todo o cidadão que tem no Estado o principal responsável pela organização dos meios para a sua efetivação. Esse direito teve seu marco inicial a partir da Constituição Federal de 1988, no qual a Educação Integral apresenta-se, como capaz de promover o desenvolvimento pleno dos educandos, considerando não somente o aspecto cognitivo, mas também o físico, o psicológico e o social, possibilitando uma melhor qualificação para o trabalho e o exercício da cidadania.

Em Belterra a Educação Integral foi implementada em 2012 por meio do Mais Educação, 5 anos após o programa ser oficializado nas demais cidades do Brasil. A demora teve como principal fator a infraestrutura precária das escolas de Belterra, pois esse programa demandava além de aumento na carga horária escolar, espaços adequados para a realização de múltiplas atividades complementares.

A reformulação do PME para o PNME mudou o foco dessa política educacional, "[...] tempos em que o pensamento neoliberal viceja nos altos circuitos do poder [...]" (FONSECA; COLARES; COSTA, 2019, p. 100), que antes era pautada na oferta de atividades diversificadas com o intuito de promover o desenvolvimento pleno do aluno, passando desde então a objetivar um melhoramento da aprendizagem em língua portuguesa e matemática no ensino fundamental, fazendo desse programa uma estratégia para reforçar os conteúdos dessas disciplinas, a fim de melhorar os índices educacionais nas provas externas, uma educação integral baseada na ampliação do tempo escolar. "Acreditamos que a referida política educacional alcançará o seu real sentido, se houver mudanças profundas por parte de todos os envolvidos." (SILVA; SANTOS, 2018, p. 206).

Uma forma de não direcionar as atividades do PNME para um reforço escolar nas escolas municipais de Belterra, foi a utilização da sequência didática, onde se organizou as atividades de ensino mediante a núcleos temáticos e procedimentais, norteando dessa maneira a aplicação intencional das atividades para favorecer o processo de aprendizagem 
dos alunos do programa. Outro fator é quanto à reorganização desses programas indutores de Educação Integral, pois as escolas tinham que realizar suas atividades em 10 e 8 meses, respectivamente, devendo usar todo o recurso proveniente desse programa para materiais de capital e de custeio, e uma vez descumpridos esses prazos as atividades ficavam sujeitas a serem reprogramadas para o ano seguinte, o que ocasionava além de um atraso no recurso do próximo ano, um descompromisso com o processo de ensino-aprendizagem dos alunos.

A Educação Integral requer a construção de um currículo que favoreça uma ampliação de conteúdos tanto disciplinares quanto de saberes locais, uma produção cultural que possibilite aos alunos compreenderem a macro e micro realidade em que estão inseridos, tendo o currículo e a cultura como processos interdependentes. E a constituição do currículo deve levar em consideração a infraestrutura que será utilizada para a sua efetivação, onde além de pensar nos espaços que podem ser usados para realizar as atividades, deve-se incluir a organização do tempo (quantitativo e qualitativo) destinado ao programa.

Para a implementação de um programa que tenha como base a ampliação de currículo, tempo e espaços, torna-se necessário também que haja uma ampliação equivalente de recursos financeiros, uma vez que esse modelo de educação tem um custo elevado, pois demanda além de materiais para serem trabalhados nas atividades, profissionais que se disponham a ministrar essas atividades.

Programas como o PME e PNME, que direcionam recursos financeiros para as escolas, são bem aceitos pela comunidade escolar, pois tornam-se uma oportunidade de estruturarem seus espaços escolares como forma de diminuir sua precariedade e possibilitar aos seus educandos ambientes mais dignos de viver. Daí a importância dos órgãos financiadores desses programas não cessarem a liberação de recursos, para que não haja uma paralização das atividades do Novo Mais Educação, como ocorreu em 2016 com o PME nas escolas públicas brasileiras.

Por fim, entendemos que enquanto os programas educacionais não deixarem de serem apenas políticas transitórias, dificilmente será realizada a efetivação de ações como políticas continuadas visando a melhoria da qualidade de vida das pessoas com ênfase na educação.

\section{REFERÊNCIAS}

ARAÚJO, D. L. 0 que é (e como faz) sequência didática? Entrepalavras, v. 3, n. 1, p. 322-334, 2013. Disponivel em: http://www.entrepalavras.ufc.br/revista/index.php/Revista/article/view/148. Acesso em: 20 fev. 2020 . 
ARROYO, M. 0 direito a tempos-espaços de um justo e digno viver. In: MOLL, J. et al. Caminhos da educação integral no Brasil: direito a outros tempos e espaços educativos. Porto Alegre: Penso, 2012. p. 33-45.

AZEVEDO, F. de et al. 0 manifesto dos pioneiros da educação nova (1932). Revista HISTEDBR On-line, p. 188-204, 2006. Edição especial. Disponível em: http://www.histedbr.fe.unicamp.br/revista/ edicoes/22e/doc1_22e.pdf. Acesso em: 20 maio 2019.

BELTERRA. Plano de Ação - Programa Mais Educação (PME) de uma escola municipal. [S. l.: s. n., 2013.

BRASIL. Constituição. Texto Constitucional de 5 de outubro de 1988, com alterações adotadas pelas Emendas Constitucionais n $1 / 92$ a n 28/2000 e emendas Constitucionais de Revisão n 1 a n 6/94. Brasilia, DF: Senado Federal, Subsecretaria de Edições Técnicas, 2000.

BRASIL. Lei n 9.394/96, de 20 de dezembro de 1996. Estabelece as diretrizes e bases da educação nacional. Diário Oficial da União, Brasilia, DF, 21 dez. 1996. Disponível em: http://www.planalto.gov.br/ ccivil_03/Leis/L9394.htm. Acesso em: 15 jun. 2019.

BRASIL. Lei n ${ }^{\circ} 13.005$, de 25 de junho de 2014. Aprova o Plano Nacional de Educação (PNE) e dá outras providências. Diário Oficial da União, Brasília, DF, 26 jun. 2014.

BRASIL. Manual Operacional de Educação Integral. Brasília, DF: MEC/SEB/DCEl, 2013. Disponível em: http://portal.mec.gov.br/index.php?option=com_docman\&view=download\&alias=14458-manual-mais ${ }^{-}$ -educacao-2013-final-171013-2-pdf\&category_slug=outubro-2013-pdf\&ltemid=30192. Acesso em: 5 jul. 2019.

BRASIL. Ministério da Educação. Fundo Nacional de Desenvolvimento da Educação. Brasília, DF: FNDE/ PDDE, [2017?]. Disponível em: https://www.fnde.gov.br/programas/pnae. Acesso em: 9 jul. 2019.

BRASIL. Ministério da Educação. Programa Novo Mais Educação Caderno de Orientações Pedagógicas - Versão I. Brasilia, DF: MEC, 17 out. 2016. Disponivel em: https://integraldf.blogspot.com/2016/10/ versao-i-do-documento-orientador-do.html. Acesso em: 9 jul. 2019.

BRASIL. Portaria $n^{\circ} 1.144 / 2016$, de 10 de novembro de 2016. Institui o Programa Novo Mais Educação, que visa melhorar a aprendizagem em língua portuguesa e matemática no ensino fundamental. Diário Oficial da União, Brasília, DF, 11 nov. 2016. Disponivel em: http://portal.mec.gov.br/index.php?option=com_ docman\&view=download\&alias=49131-port-1144mais-educ-pdf\&category_slug=outubro-2016pdf\&ltemid=30192\%20\%3E. Acesso em: 17 jun. 2019.

BRASIL. Portaria Normativa Interministerial $n^{\circ} 17$, de 24 de abril de 2007. institui o Programa Mais Educação, que visa fomentar a educação integral de crianças, adolescentes e jovens, por meio do apoio a atividades sócio-educativas no contraturno escolar. Diário Oficial da União, Brasília, DF, 26 abr. 2007. 
BRASIL. Resolução/CD/FNDE n 1, de 8 de fevereiro de 2017. Altera o valor per capita para oferta da alimentação escolar do Programa de Alimentação Escolar - PNAE. Diário Oficial da União, Brasília, DF, 9 fev. 2017. Disponível em: http://www.fnde.gov.br/acesso-a-informacao/instituciona//legislacao/ item/10900-resolu\%C3\%A7\%C3\%A3o-cd-fnde-mec-n\%C2\%BA-1,-de-8-de-fevereiro-de-2017. Acesso em: 12 jul. 2019.

BRASIL. Resolução/CD/FNDE n²6, de 17 de junho de 2013. Dispõe sobre o atendimento da alimentação escolar aos alunos da educação básica no âmbito do Programa Nacional de Alimentação Escolar (PNAE). Diário Oficial da União, Brasília, DF, 18 jun. 2013.

BRASIL. Resolução $n^{\circ}$ 67, de 28 de dezembro de 2009. Altera o valor per capita para oferta da alimentação escolar do Programa Nacional de Alimentação Escolar - PNAE. Diário Oficial da União, Brasilia, DF, 29 dez. 2009. Brasilia, DF: MEC, 2009. Disponível em: https://www.fnde.gov.br/index. php/acesso-a-informacao/instituciona//legislacao/item/3376-resolu\%C3\%A7\%C3\%A3o-cd-fnde-n\%C2\%BA-67-de-28-de-dezembro-de-2009. Acesso em: 09 jul. 2019.

CAVALIERE, A. M. V. Tempo de escola e qualidade na educação pública. Educ. Soc., v. 28, n. 100, p. 10151035, out. 2007. Edição Especial. Disponivel em: http://www.scielo.br/pdf/es/v28n100/a1828100.pdf. Acesso em: 20 jul. 2019

COELHO, L. M. C. da C. História(s) da educação integral. Em Aberto, v. 22, n. 80, p. 83-96, abr. 2009. Disponível em: http://rbepold.inep.gov.br/index.php/emaberto/article/viewFile/2222/2189. Acesso em: 23 jul. 2019

ESQUINSANI, S. S. A educação como um direito: o desafio da qualidade em uma experiência de escola pública. Roteiro, v. 35, n. 2, p. 251-268, 17 ago. 2010. Disponível em: https://portalperiodicos.unoesc.edu. $\mathrm{br} /$ roteiro/article/view/251. Acesso em: 14 abr. 2020.

FERREIRA, G. V. Educação de Tempo Integral em Santarém: ações da secretaria municipal de educação no período de 2008 a 2014. 2016. Dissertação (Mestrado em Educação) - Instituto de Ciências da Educação, Universidade Federal do Oeste do Pará, Pará, 2016.

FONSECA, A.; COLARES, A.; DA COSTA, S. Educação infantil: história, formação e desafios. Educação \& Formação, v. 4, n. 3, p. 82-103, 2 set. 2019. Disponivel em: https://revistas.uece.br/index.php/redufor/ article/view/1270. Acesso em: 13 abr. 2020.

GADOTTI, M. Educação Integral no Brasil: inovações em processo. São Paulo: Editora e Livraria Instituto Paulo Freire, 2009. Disponivel em: https://drive.google.com/file/d/0Bwe6vB7NVKTmVml0RDRKNVhiZmM/ view. Acesso em: 16 ago. 2019.

GOMES, T. C. A educação integral e o Programa Ensino Médio Inovador ProEMl: singularidades desta política em uma escola estadual. 2017. Dissertação (Mestrado em Educação) - Universidade Federal do Oeste do Pará, Santarém, 2017. Disponível em: https://drive.google.com/file/ d/10QeekZj9oVEIZcYlq9ZN9j_KbZJpYJ3Z/view. Acesso em: 16 ago. 2019 
GOMES, T. C.; COLARES, M. L. I. S. A política de educação integral em tempo integral: a perspectiva dos professores. Práxis Educacional, v. 15, n. 31, p. 313-332, jan. 2019. Disponível em: http://periodicos2. uesb.br/index.php/praxis/article/view/4675. Acesso em: 16 abr. 2020.

IBGE. Dados do Censo Cidades: Belterra. [S. L]: IBGE, 2010. Disponível em: www.cidades.bge.gov.br. Acesso em: $10 \mathrm{abr}$. 2019.

IBGE. Dados do Censo Cidades: Belterra. [S. l]: IBGE, 2017. Disponível em: www.cidades.ibge.gov.br. Acesso em: 11 abr. 2019.

JACOMELI, M. R. M.; BARÃO, G. O. D.; GONÇALVES, L. A política de educação integral no Brasil e suas relações com as diretrizes da conferência de Jomtien. Revista Exitus, v. 8, n. 3, p. 32-57, 2018. Disponível em: http://www.ufopa.edu.br/portaldeperiodicos/index.php/revistaexitus/article/view/638.

Acesso em: 10 mar. 2020.

MACEDO, L. de et al. Intervenção com jogos: estudo sobre o Tangram. Psicologia Escolar e Educacional, v. 19, n. 1, p. 13-22, 2015. Disponível em: http://www.scielo.br/pdf/pee/v19n1/2175-3539pee-19-01-00013.pdf. Acesso em: 18 set. 2019.

MACIEL, A. C. Marx e a Politecnia, ou: do princípio educativo ao princípio pedagógico. Revista Exitus, v. 8, n 2, p. 85-110, maio/ago. 2018. Disponivel em: http://www.ufopa.edu.br/portaldeperiodicos/index.php/ revistaexitus/article/view/530. Acesso em: 11 abr. 2020.

MAURÍCIO, L. V. Condições e interesses pela educação em tempo integral no Brasil. Revista Educação e Cultura Contemporânea, v. 13, n. 33, p. 84-100, 2016. Disponivel em: http://periodicos.estacio.br/index. php/reeduc/article/viewArticle/2436. Acesso em: 10 jul. 2019.

MONTEIRO, M. P. C. 0 Programa Novo Mais Educação: uma avaliação política da Política. 2018. Tese (Doutorado) - Programa de Pós-graduação em Políticas Públicas/CCSO, Universidade Federal do Maranhão, São Luís, 2018. Disponível em: https://tedebc.ufma.br/jspui/bitstream/tede/2535/2/ M\%c3\%b4nicaMonteiro.pdf. Acesso em: 25 ago. 2019.

SANTOS, Â. R. dos; COLARES, M. L. I. S. Política educacional no âmbito municipal: experiência no interior da Amazônia. Revista Tempos e Espaços em Educação, v. 12, n. 31, p. 319-338, 2019. Disponível em: https://seer.ufs.br/index.php/revtee/article/view/11733. Acesso em: 13 abr. 2020.

SILVA, L; SANTOS, A. A prática pedagógica dos professores que lecionam a EJA no município de lbirataia-BA. Educação \& Formação, v. 3, n. 2, p. 191-209, 2 maio 2018. Disponivel em: https://revistas.uece. $\mathrm{br} /$ index.php/redufor/article/view/277. Acesso em: 13 fev. 2021.

SILVA, N. F. da; COLARES, M. L. I. S. A Educação Integral no Oeste do Pará: o estado do conhecimento a partir das dissertações do PPGE-UFOPA. Práxis Educacional, v. 16, n. 39, p. 379-394, abr. 2020. Disponível em: http://periodicos2.uesb.br/index.php/praxis/article/view/6386. Acesso em: 10 abr. 2020. 
SOARES, L. de V.; COLARES, M. L. I. S. Avaliação educacional ou política de resultados? Educação \& Formação, v. 5, n. 3, p. e2951, 27 maio 2020. Disponivel em: https://revistas.uece.br/index.php/redufor/ article/view/2951. Acesso em: 13 fev. 2021

SOUSA, L. T.; COLARES, M. L. I. S. 0 Programa Mais Educação (PME) no Município de Belterra/PA: percepção da equipe gestora. Revista Linguagens, Educação e Sociedade, ano 23, n. 38, jan./jul. 2018. Disponivel em: https://revistas.ufpi.br/index.php/lingedusoc/article/view/7138/pdf. Acesso em: 14 abr. 2020.

Endereço para correspondência: Rua Japauá, 376, Floresta, 68025-140, Santarém, Pará, Brasil; lya. ufopa@gmail.com 